\title{
KEMITRAAN PEMERINTAH DENGAN ASITA DALAM PROMOSI KUNJUNGAN WISATA DI DINAS KEBUDAYAAN DAN KEPARIWISATAAN PROVINSI SULAWESI SELATAN
}

\author{
RUDI $^{1}$, LUKMAN HAKIM ${ }^{2}$, ANSYARI MONE \\ ${ }^{1)}$ Mahasiswa Jurusan Ilmu Administrasi Negara Unismuh Makassar \\ ${ }^{2)}$ Dosen Ilmu Administrasi Negara Unismuh Makassar \\ 3) Dosen Ilmu Administrasi Negara Unismuh Makassar
}

\begin{abstract}
The purpose of this research is to know the partnership Government with Asita in the promotion of tourism visits in South Sulawesi. This type of research is qualitative. The source of data in this study is the primary and the secondary. The way of data collection used instruments in the form observation, interviews and documentation. This research result indicate that a partnership between the Government with Asita is good.. This can be seen from some of the partnership established the subcontracting partnership, the agenct partnership and the venture capital partnership. The partnership pattern most prominent of this partnership is the agent partnership. The success partnertship of governtment with Asita can be seen from an increase tourist arrivals in South Sulawesi.
\end{abstract}

Keywords: partnership, governtment, visits tourism

\begin{abstract}
ABSTRAK
Tujuan dari penelitian ini adalah untuk mengetahui kemitraan pemerintah dengan Asita dalam promosi kunjungan wisata di Sulawesi Selatan. Jenis penelitian ini adalah kualitatif. Sumber data dalam penelitian ini adalah data primer dan data sekunder. Tekhnik pengumpulan data menggunakan instrumen berupa observasi, wawancara dan dokumentasi. Hasil penelitian ini menunjukkan bahwa kemitraan antara Pemerintah dengan Asita berjalan baik. Hal ini dapat dilihat dari beberapa pola kemitraan yang terjalin yaitu pola kemitraan subkontrak, pola kemitraan keagenan dan pola kemitraan modal ventura. Pola kemitraan yang paling menonjol dari kemitraan ini adalah pola kemitraan keagenan. Keberhasilan mitra pemerintah dengan Asita dapat dilihat dari peningkatan kunjungan wisatawan di Sulawesi Selatan.
\end{abstract}

Kata kunci: kemitraan, pemerintah, kunjungan wisatawan. 


\section{PENDAHULUAN}

Berdasarkan data Badan Pusat Statistik (BPS) Sulawesi Selatan, wisatawan asing yang berkunjung ke Sulawesi Selatan melalui pintu masuk Bandara Sultan Hasanuddin pada 2012 sebanyak 9.440 orang dan masih didominasi wisman dari sejumlah negara di kawasan Asia. Pergerakan wisman yang berkunjung ke Sulsel tahun 2013 melejit 11.036 menjadi $32,81 \%$ dibandingkan tahun lalu. Sedangkan wisatawan mancanegara yang berkunjung ke Sulawesi Selatan periode Januari-Oktober 2014 tumbuh $35,81 \%$ dari kunjungan wisman periode yang sama tahun lalu yang mencapai 14.657 orang. Berdasarkan data kunjungan pariwisata domestik maupun mancanegara yang terus meningkat tiap tahunnya tersebut, sudah jelas jika Sulawesi selatan mempunyai potensi pariwisata yang cukup menjanjikan dan sangat diminati wisawatan asing maupun lokaal dan harus terus dikembangkan.
Dalam usaha pengembangan dan peningkatan promosi kunjungan wisata tentunya telah dirancang dan dipersiapkan matang-matang baik dari segi materi maupun aturan-aturan yang dipedomani. Pemerintah harus terus melakukan pertimbangan dan perbaikan ataupun membuat peraturan baru yang diharapkan dapat meningkatkan kualitas sektor kepariwisataan di Sulawesi Selatan mengingat sektor pariwisata sangat penting dan bisa menjadi andalan di Sulawesi Selatan dan menjadi salah satu salah satu pilar pembangunan Sulawesi Selatan (Taslim, 2014).

Penyelanggaraan kepariwisataan di Sulawesi Selatan terutama dalam hal kemitraan pemerintah dengan swasta dalam promosi kunjungan wisata diatur dalam Peraturan Daerah Provinsi Sulawesi Selatan nomor 1 tahun 2011 tentang Penyelanggaraan Kepariwisataan di Sulawesi Selatan. Penyelenggaraan kepariwisataan yang dimaksud telah tercantum dalam Peraturan Daerah provinsi Sulawesi Selatan nomor 1 tahun 2011 Bab I 
Pasal 7 adalah kelembagaan kepariwisataan, usaha pariwisata, destinasi pariwisata dan pemasaran. Di samping itu pemerintah juga mempunyai perda RIPPNAS (Rencana Induk Pengembangan Pariwisata Nasional) yang kemudian dijabarkan menjadi RIPP Provinsi Sulawesi Selatan dan Rencana Induk Pengembangan Pariwisata Daerah (RIPPDA).

Pariwisata itu hendaknya ditempatkan sebagai wahana pengabdian dan perjuangan dalam mewujudkan kehidupan berbangsa dan bernegara yang aman, damai, maju, berkesejahteraan dan berperadaban (Sutowo, 2007).

Sejalan dengan tuntutan transparansi dan akuntabilitasi publik, maka kebijakan pariwisata harus bersifat terbuka, mudah dipahami dan diakses oleh masyarakat dan kalangan bisnis. Untuk kepentingan itu, dibutuhkan data yang akurat, terpercaya dan konsisten yang meliputi aspek-aspek yang terkait dengan dunia pariwisata. Disamping itu, agar terlihat asas manfaat untuk msyarakat luas, perlu penyajian informasi yang jelas dan menyeluruh dalam bentuk laporan yang mudah dipahami. Dengan adanya informasi pariwisata yang kompeherensif, masyarakat dan dunia usaha diharapkan akan lebih memberikan perhatian dan bersedia bekerjasama dengan pemerintah sektor pariwisata di Sulawesi Selatan (Tadjoeddin, 2005).

Menurut Hafsah (2000: 39), "Kemitraan adalah suatu strategi bisnis yang dilakukan oleh dua pihak atau lebih dalam jangka waktu tertentu untuk meraih keuntungan bersama dengan prinsip saling membutuhkan dan saling membesarkan. Kemitraan adalah suatu kerja sama formal antara individu kelompok-kelompok atau organisasi-organisasi untuk mencapai suatu tugas atau tujuan tertentu (Notoatmodjo, 2003).

Anoraga (2002: 232) kemitraan merupakan suatu bentuk jalinan 
kerjasama dari dua atau lebih pelaku usaha yang saling menguntungkan.

Adapun tujuan kemitraan yang dikemukakan oleh Hafsah (2000: 43), ialah:a. Meningkatkan pendapat usaha kecil dan masyarakat. b. Meningkatkan perbolehan nilai tambah bagi pelaku kemitraan.c. Meningkat pemeran dan pemberdayaan masyarakat. $\mathrm{d}$ Meningkatkan pertumbuhan ekonomi pedesaan, wilayah dan nasional.e. Memperluas kesempatan kerja.f. Meningkatkan ketahanan ekonomi nasional.

Kemitraan didefenisikan sebagai hubungan sukarela dan bersifat kerjasama antara beberapa pihak, baik pemerintah maupun swasta, yang semua orang didalamnya setuju untuk bekerjasama dalam meraih tujuan bersama dan menunaikan kewajiban tertentu serta menanggung resiko, tanggungjawab, sumberdaya, kemampuan dan keuntungan secarabersama-sama. Kunci utama terlaksananya kemitraan adalah dengan menerapkan kerjasama/koordinasi dan kolaborasi seluruh program-program dengan lembaga-lembaga terkait yang berpartisipasi dalam kemitraan tersebut (Jayagiri, 2012).

Farazmand (2009: 20) menyatakan bahwa "bangsa dan nilai sinergi merupakan inti dari kemitraan, baik di tingkat lokal, nasional atau global". Kemitraan disini pada esensinya adalah dikenal dengan istilah gotong royong atau kerjasama dari berbagai pihak, baik secara individual maupun kelompok dalam pengelolaan Pariwisata.

Menurut Sulistyani (2004: 129), kemitraan dari perspektif etimologis diadaptasi dari kata partnership dan berasal dari akar kata partner, partner dapat diterjemahkan "pasangan, jodoh, sekutu, atau komponen", sedangkan partnership diterjemahkan menjadi persekutuan atau perkongsian.

Kemitraan yang diterapkan dalam pengembangan dan pengelolaan pariwisata harus mempunyai konsep yang jelas dan memberikan manfaat masyarakat sekitar. Kemitraan infrastruktur antara pemerintah dan 
pihak swasta memiliki beberapa konsep yang dimulai dari fully public (pemerintah secara penuh) sampai fully private (swasta secara penuh), Savas (2000: 64).

Secara umum, model kemitraan dikelompokkam menjadi dua (Notoadmodjo, 2007) yaitu: 1. Model I: model kemitraan yang paling sederhana adalah dalam bentuk jaringan kerja (networking) atau building linkages. Kemitraan ini berbentuk jaringan kerja saja. Masingmasing mitra memiliki mitra tersendiri melalui perencanaannya, pelaksanaannya hingga evaluasi. Jaringan tersebut terbentuk karena adanya persamaan pelayananan atau karakteristik lainnya. 2. Model II: Kemitraan model II ini lebih baik dan solid dibandingkan model I. hal ini karena setiap mitra memiliki tanggung jawab yang lebih besar terhadap program bersama. Visi, misi dan kegiatan-kegiatan dalam mencapai tujuan kemitraan direncakan, dilaksanakan, dan dievaluasi bersama.

$\begin{array}{rrr}\text { Selama } & \text { menjalin } & \text { kegiatan } \\ \text { kemitraan, } & \text { aspek-aspek } & \text { yang }\end{array}$

dikerjasamakan diantara pihak pemerintah dan ASITA ialah: 1. Program Kegiatan: Program kegiatan bersama dengan lembaga mitra merancang program bersama. Pada pelaksanaannya paling tidak ada tiga kemungkinan bentuk kerjasma yang dapay dilakukan yaitu: (a) bersama melaksanakan kegiatan pada setiap tahapan pengelolaan program, (b) Sebuah lembaga melakukan bagian kegiatan pada tahapan pengelolaan program, (c) Sebuah lembaga melaksanakan program kegiatan awal atau lanjutan dari program kegiatan awal atau lanjutan dari program kegiatan yang telah dirancang oleh lembaga lain. 2. Sarana dan Prasarana: Yang dimaksudkan dalam bagian ini adalah sarana dan prasarana kegiatan pengembangan program, seperti: tempat atau gedung dan peralatan kesenian. Bentuk kemitraan dapat dilakukan secara timbal balik. Sebuah lembaga dapat memanfaatkan sarana dan prasarana lembaga lain atau sebaliknya, 3. Dana: Dana merupakan salah satu faktor utama yang menunjang berjalannya sebuah 
program, kemitraan dengan lembaga lain yang memiliki dana perlu dijalin dalam rangka menjaring lembaga donor guna mewujudkan sebuah program yang akan dilaksanakan, 4. Tenaga: Kemitraan dibidang ini dapat dilakukan secara timbal balik. Tenaga yang memadai (kualified) yang dimiliki oleh sebuah lembaga dapat dijadikan untuk didayagunakan oleh lembaga lain dan begitupun sebaliknya.

\section{METODE PENELITIAN}

Penelitian ini dilaksanakan di Kantor Dinas Kebudayaan dan Kepariwisataan Provinsi Sulawesi Selatan. Waktu penelitian ini dari Oktober sampai Desember2015.

$$
\text { Jenis penelitian yang }
$$

digunakan yaitu kualitatif, artinya data yang diperoleh berupa data-data, gambaran, perilaku dan tidak dituangkan dalam bentuk angka melainkan tetap dalam bentuk kualitatif yang memiliki arti lebih kaya dari sekedar angka atau frekuensi. Interpretasi terhadap isi dibuat dan disusun secara sistematik/menyeluruh. Tipe penelitian ini bersifat deskriptif, yaitu penggambaran suatu fenomena dengan kata-kata bukan denganangkaangka.

Sumber data penelitian ini adalah data primer, data yang diperoleh peneliti dari hasil wawancara yang terdiri dari beberapa informan, serta dokumentasi dan observasi atau pengamatan langsung terhadap objek yang diteliti. Sedangkan data sekunder adalah data yang diperoleh peneliti bersumber dari bahan bacaan atau dokumentasi yang berhubungan dengan objek penelitian yang bersumber dari buku bacaan dan Internet.

Informandalam kegiatan penelitian ini ialah, Kepala Dinas Kebudayaan dan Kepariwisataan Provinsi Sulawesi Selatan, Staf-staf Dinas Kebudayaan dan Kepariwisataan Provinsi Sulawesi Selatan, Pimpinan ASITA, Sekretaris dan staf pegawai ASITA dengan jumlah keseluruhan adalah sebanyak 7 orang. 
Penulis menggunakan beberapa tekhnik pengumpulan data yaitu observasi, dokumentasi dan wawancara.

Penelitian ini menggunakan metode induktif untuk menarik suatu kesimpulan terhadap hal-hal dari datadata yang telah dikumpulkan melalui observasi, studi kepustakaan dan wawancara yang bisa digeneralisasikan untuk menilai faktafakta empiris yang ditemukan lalu dicocokkan dengan teori-teori yang ada.

Menurut Sugiyono (2012), tekhnik pengumpulan data triangulasi diartikan sebagai tekhnik pengumpulan data yang bersifat menggabungkan dari berbagai teknik pengumpulan data dan sumber data yang telah ada. Menurut Sugiyono ada 3 macam triangulasi, yaitu Triangulasi Sumber, Triangulasi Teknik dan Triangulasi Waktu.

\section{HASIL DAN PEMBAHASAN}

Sulawesi selatan adalah sebuah Provinsi yang terletak di bagian timur
Indonesia, ber-ibu kota Makassar. Sulawesi Selatan terletak di jazirah Selatan Pulau Sulawesi. Provinsi yang Beribukota di Makassar ini, terletak antara : $0^{\circ} 12^{\prime}-8^{\circ}$ Lintang Selatan . $116^{\circ} 48^{\prime}$ - $122^{\circ} 36^{\prime}$ Bujur Timur. Secara administratif berbatasan: Sebelah Utara dengan Provinsi Sulawesi Tengah Sebelah Barat dengan Selat Makassar. Sebelah Timur dengan Teluk Bone Sebelah Selatan dengan Laut Flores Luas wilayahnya, $62.482,54 \mathrm{~km} 2$ (42\% dari luas seluruh pulau Sulawesi dan 4,1 \% dari Luas seluruh Indonesia).

Dinas Kebudayaan dan Kepariwisataan Provinsi Sulawesi Selatan berdasarkan Peraturan Gubernur Nomor 16 Tahun 2009 tentang Tugas Pokok, Fungsi dan Rincian Tugas Jabatan Struktural, maka susunan organisasi dinas ini terdiri dari Kepala Dinas, Sekretariat, Bidang Sejarah dan Purbakala, Bidang Senidan Film, Bidang Pengembangan Destinasi Pariwisata, Bidang Pemasaran, Sub Bagian dan Seksi.

Sekretariat terdiri atas Sub Bagian Umum dan Kepegawaian, 
Subb Bagian Program dan Sub Bagian Keuangan yang bertugas mengoordinasikan kegiatan, memberikan pelayanan teknis dan administrasi urusan umum dan kepegawaian, keuangan serta penyusunan program dalam lingkungan Dinas Kebudayaan dan Kepariwisataan.

Pengertian pariwisata sebagai Agent of Development adalah pariwisata merupakan suatu industri yang diharapkan sebagai sumber perolehan devisa negara, dapat meningkatkan kesempatan berusaha, kesempatan kerja, mempercepat proses pemerataan pendapatan $(R e-$ Distribution of Income), meningkatkan pendapatan nasional (National Income), memperkuat citra bangsa dimata Internasional.

Dinas Kebudayaan dan Pariwisata Provinsi Sulawesi Selatan mempunyai visi yaitu: "Mewujudkan pelayanan terbaik dalam pelestarian dan pengembangan kebudayaan serta pengembangan kepariwisataan." Dengan ini diketahui bahwa pemerintah daerah Provinsi Sulawesi
Selatan mempunyai visi dan misi yang telah dibuat sebagai landasan pencapaian target dibidang pariwisata. Sedangkan misi dan visi dari promosi pariwisata Provinsi Sulawesi Selatan ialah meningkatkan jumlah kunjungan wisatawan baik domestik maupun mancanegara dengan harapan meningkatkan pendapatan asli dareah (PAD).

ASITA didirikan tanggal 7 Januari 1971. Diluncurkan di Jakarta pada 7 Januari 1971, Asosiasiation The Indonesia Tours \& Travel Agencies (ASITA) adalah satu-satunya diakui secara hukum, aliansi non-profit dari kewirausahaan wisata Indonesia. Beroperasi di bawah UU RI No. 9/1990 tentang Pariwisata, ASITA memberikan kepemimpinan untuk upaya komunal agen perjalanan Indonesia. ASITA Provinsi Sulawesi Selatan berlokasi tepat di dalam Kantor Dinas Kebudayaan dan Kepariwisataan Sulawesi Selatan sehingga memberikan kemudahan keduanya dalam bekerja sama atau bermitra.

ASITA memiliki visi untuk 
melayani dan melindungi kepentingan anggotanya, untuk memediasi kepentingan pariwisata terkait apapun, baik untuk anggota dan pihak eksternal, Melestarikan hubungan yang harmonis dan kerjasama dalam keanggotaannya dan eksternal, dengan pihak yang berkaitan dengan pariwisata dan non-pariwisata terkait baik, untuk meningkatkan citra industri pariwisata Indonesia dengan memastikan kepuasan dan keamanan, sementara juga melindungi dan menjamin kebutuhan pelanggan dan pihak lain yang terlibat dalam asosiasi, tanpa mengorbankan kebutuhan anggotanya.

Misi ASITA ialah menyiapkan struktur dan melakukan upaya untuk meningkatkan pembangunan, nilai dan kualitas perjalanan dan pariwisata Indonesia untuk kepentingan keanggotaannya.

Menurut Peraturan Daerah Provinsi Sulawesi Selatan Nomor 1 Tahun 2011 Tentang Penyelanggaraan Kepariwisataan di Sulawesi Selatan yang telah tercantum dalam Peraturan
Daerah Nomor 1 Tahun 2011 Bab I Pasal 7 adalah kelembagaan kepariwisataan, usaha pariwisata, destinasi pariwisata dan pemasaran. Maka diharapkan dengan adanya sektor swasta dalam hal ini ASITA (Asosiasi Industri Travel) dapat memberi kontribusi yang baik terhadap peningkatan promosi kunjungan wisata di Sulawesi Selatan. ASITA berperan dalam memediasi industri-industri travel yang ada di Sulawesi Selatan agar memberikan pelayananyang baik kepada wisatawan yang berkunjung ke Sulawesi Selatan dalam hal travel atau memberi kepuasan wisatawan dalam perjalanan menuju destinasi wisata yang ada di Sulawesi Selatan. Tetapi, peranan ASITA ini masih kurang optimal karena destinasi wisata yang terekspos di masyarakat wisatawan lokal dan asing masih sebagian kecil padahal banyak kawasan wisata yang bisa diangkat dan bernilai lebih fresh dimata wisatawan.

Salah satu kemitraan yang dilakukan antara Dinas Kebudayaan dan Kepariwisataan secara berkesinambungan ialah pada event 
Celebes Travel Mart (CTM).Celebes

Travel Marttersebut telah berlangsung selama tiga tahun dan rencananya akan dilaksanakan setiap tahunnya. Kegiatan tersebut bertujuan untuk menggalang para pelaku bisnis dibidang pariwisata baik lokal maupun mancanegara.

Pola inti plasma adalah pola hubungan kemitraan antara pemerintah dengan swasta yang di dalamnya pihak pemerintah sebagai inti sedangkan pihak swasta sebagai plasma. Pemerintah melaksanaan pembinaan mulai dari penyediaan sarana produksi, bimbingan teknis, sampai dengan pemasaran hasil produksi.Kegiatankegiatan yang melibatkan kedua belah pihak dalam hal kemitraan pengembangan SDM diantaranya Rapat Kerja, Workshop travel, Diklat dll.

Berbagai macam program upaya pengembangan nyata yang dilakukan dengan ASITA sebagai mitra yang sangat dekat contohnya workshop dan pelatihan-pelatihan Tour Guide dimana pihak disbudpar yang mendatangkan langsung pemateri dari kementerian kebudayaan dan pariwisata pusat.Harus ada ide-ide yang lebih kreatif dan inovatif dari kedua pihak dalam artian pihak swasta dan pemerintah.Salah satu hal yang harus dijaga adalah komunikasi agar tercipta ide-ide yang dapat disalurkan dan dikolaborasikan kedalam sebuah program.

$$
\text { Pemerintah mempunyai }
$$
tanggung jawab dengan memfasilitasi dan memediasi pihak ASITA dengan kementrian kebudayaan dan kepariwisataan pusat dalam hal sosialisasi-sosialisasi dan penyuluhanpenyuluhan dengan menghadirkan narasumber dari kementrian sebagai pemateri dalam sosialisasi.

Sesuai dengan hasil wawancara bahwa hubungan kerjasama kedua pihak sangat kuat meskipun tidak ada kontrak kerjasama yang mengatur diantara keduanya. Hal tersebut dapat dilihat dari partisipasi kedua belah pihak yang sangat kuat dalam hal pengembangan SDM dan kesadaran akan pentingnya pengembanganpengembangan di sektor pariwisata yang merupakan bidang yang 
berpengaruh pada perekonomian Sulawesi Selatan.Memang banyak kegiatan yang telah terealisasi tetapi destinasi-destinasi wisata yang difokuskan hanyalah sebagian kecil dan itu-itu saja padahal Sulawesi Selatan punya banyak destinasi yang lebih fresh dan menarik.

Kedua pihak harus terus berinovasi dan bereksperimen untuk melahirkan ide-ide yang pantas menjurus kepada peningkatan kunjungan wisatawan. Kegiatankegiatan yang telah dilaksanakan seperti sosialisasi-sosialisasi atau penyuluhan "Tour Guide" dan perhotelan, program sadar wisata maupun pameran travel kiranya belum cukup untuk mengeksplore Sulawesi Selatan yang kaya dengan destinasi wisatanya tersebut.

Pola subkontrak adalah hubungan kemitraan antara ASITA dengan Dinas Kebudayaan dan Kepariwisataan Provinsi Sulawesi Selatan yang didalamnya ASITA memproduksi komponen yang diperlukan oleh Dinas Kebudayaan dan Kepariwisataan Provinsi Sulawesi Selatan sebagai bagian dari produksinya. Menurut pegawai Dinas Kebudayaan dan Kepariwisataan Provinsi Sulawesi Selatan bahwa proses kemitraan yang terjadi antara Dinas Kebudayaan dan Kepariwisataan dengan pihak ASITA selalu didukung oleh bidang-bidang yang ada di dalamnya demi kelancaran proses kemitraannya. Bidang-bidang di Dinas Kebudayaan dan Kepariwisataan Provinsi Sulawesi Selatan yang selalu aktif dalam kegiatan ASITA adalah bidang seni dan film.Bidang seni dan film tersebut selalu mengambil bagian dari seni pertunjukan hiburan dan penyediaan alat-alat musik tradisional dan kesenian, artistik dan dekorasi area kegiatan.

Ditarik kesimpulan bahwa setiap komponen yang dibutuhkan terkhusus dibidang travel atau transportasi, selalu disediakan atau didukung oleh pihak ASITA sesuai dengan permintaan pihak Dinas Kebudayaan dan Kepariwisataan Provinsi Sulawesi Selatan.Transportasi 
yang dimaksudkan ialah bus-bus pariwisata dan kapal-kapal air jika destinasinya ialah kepulauan.Selain itu, keperluan-keperluan lain seperti penginapan atau villa di destinasi wisata yang dituju selalu disediakan. Hal tersebut adalah salah satu keperluan pokok mengingat keamanan wisatawan harus terjamin, nyaman dan tidak menimbulkan ketakutan agar nama baik destinasi wisata di Sulawesi Selatan terjaga dengan baik.

Pola dagang umum ialah hubungan kemitraan antara swasta (ASITA) dengan Dinas Kebudayaan dan Kepariwisataan Provinsi Sulawesi Selatan yang di dalamnya Dinas Kebudayaan dan Kepariwisataan Provinsi Sulawesi Selatan yang memasarkan produksi usaha ASITA. ASITA yang notabenenya menaungi banyak usaha travel tentunya memiliki karakter dan bidang yang mencakup kemampuan yang berbeda-beda pula. Ada usaha travel yang melayani perjalan local seperti perjalanan destinasidalam negeri dan domestic atau mancanegara. Kesemuanya itu telah tertata rapi dan terkordinir dengan sedemikian rupa sehingga kecil kemungkinan adanya gesekan persaingan yang tak sehat. Diantara banyaknya usaha travel.

Mencermati pernyataan di atas, dapat disimpulkan bahwa diantara keduanya dan terkhusus kepada Dinas Kebudayaan dan Kepariwisataan Provinsi Sulawesi Selatan tidak mempromosikan atau merekomendasikan produk yang berada di bawah naungan ASITA Sulawesi Selatan secara langsung karena keduanya hanya bermitra dalam bentuk program-program dan kegiatan yang berhubungan dengan keduanya. Akan tetapi, secara tidak langsung pihak Disbudpar akan memunculkan imej yang baik kepada usaha travel yang ada di bawah naungan ASITA saat sedang berlangsung mitra-mitra dilapangan.

Pola kemitraan waralaba ialah hubungan kemitraan yang di dalamnya Dinas Kebudayaan dan Kepariwisataan Provinsi Sulawesi Selatan pemberi waralaba memberikan hak penggunaan lisensi merk dan saluran distribusi perusahaan kepada 
swasta (ASITA) penerima waralaba dengan disertai bantuan dan bimbingan manajemen.

Hubungan mitra antara kedua belah pihak sangat erat dan tak bisa dipisahkan antara satu sama lain. Keduanya bergerak dibidang pariwisata dan keduanya pun saling membutuhkan dan melengkapi, salah satunya adalah kebutuhan akan informasi dan data-data lainnya.Dalm setiap pertemuan kedua pihak, selalu terjadi sharing dan masukan-masukan yang membangun. Terjadi pertukaran ide-ide yang akan disusun dan menjadi perencanaan program.

\section{Pernyataan Staf Bidang} Pemasaran di atas senada atau selaras dengan apa yang dikemukakan oleh Staf ASITA ialah bahwa prinsipprinsip musyawarah tetap selalu diutamakan oleh kedua belah pihak guna saling menguntungkan dari segi kinerja antara keduanya.Komunikasi yang terjalin sangat harmonis dan berlangsung baik atau efektif.Intinya kedua pihak dalam hal kemitraannya sangat mendukung dan menguntungkan antara satu sama lain. Diantaranya keduanya, prioritas utama adalah kemajuan pariwisata karena dengan majunya wisata Sulawesi Selatan maka pengguna jasa travel pun meningkat dan tentunya akan menguntungkan usaha-usaha travel yang dinaungi oleh ASITA.

Pola keagenan adalah hubungan mitra yang di dalamnya ASITA diberi hak khusus untuk memasarkan produk Dinas Kebudayaan dan Kepariwisataan Provinsi Sulawesi Selatan sebagai mitranya. Pegawai Disbudpar berpendapat bahwa: Dalam hal keagenan, memanglah jelas peran ASITA sebagai pihak yang berinteraksi dengan buyers di mancanegara maupun lokal. Pihak ASITA diberi hak khusus untuk memasarkan dan mempromosikan destinasi-destinasi wisata di 21 kabupaten dan 3 kabupaten kota yang ada di Sulawesi Selatan.Dalam lobynya dengan buyers mereka yang menjadi objek-objek promosi adalah 
destinasi-destinasi Sulawesi Selatan yang merupakan produk-produk dari Dinas Kebudayaan

dan Kepariwisataan Provinsi Sulawesi Selatan.

Pernyataan di atas senada dengan yang dikemukakan oleh Sekretaris DPD Asita bahwa produkproduk Dinas Kebudayaan dan Kepariwisataan Provinsi Sulawesi Selatan yang dimaksud dalam hal ini adalah destinasi-destinasi atau ODTW (Objek daerah tujuan wisata) dipasarkan atau dipromosikan oleh pihak ASITA. Seiring dengan kegiatan promosi yang dilakukanoleh ASITA, mereka mengambil kesempatan untuk menawarkan produk mereka sendiri sebagai penyedia sarana travel atau transportasi menuju destinasi-destinasi wisata tersebut. Dengan segala kemampuan maka mereka memberi pelayanan yang terbaik demi kepuasan dan kenyaman wisatawan agar kunjungan wisata selanjutnya akan meningkat. Maka keduanya dapat dikatakan sebagai mitra yang sifatnya saling
menguntungkan(SymbosisMutualisme)

Jika diinterpretasi dengan mendalam maka pola kemitraan keagenan inilah yang paling menonjol antara Dinas Kebudayaan dan Kepariwisataan Provinsi Sulawesi Selatan dengan ASITA. Alasannya, setiap program-program dan kemitraan yang dilakukan selalu menjadikan produk wisata Dinas Kebudayaan dan Kepariwisataanlah yang dipasarkan dalam kata lain didistribusikan Pengertian agen hampir sama dengan distributor karena sama-sama menjadi perantara dalam memasarkan barang dan jasa perusahaan menengah atau besar (Prisipal).

Modal ventura dapat didefenisikan sebagai pembiayaan atau penyertaan modal pemerintah kepada mitranya ataupun sebaliknya. Modal ventura juga bisa dikatakan sebagai peminjaman modal sesuai dengan kesepakatan-kesepakatan kedua belah pihak. Sebagaimana yang dikemukakan oleh Staf Bidang Kerjasama Disbudpar bahwa: Dalam setiap lembaga atau organisasi, dana 
adalah kendala utama. Dana yang digunakan dalam program-program kegiatan Dinas Kebudayaan dan Pariwisata Provinsi Sulawesi Selatan asalnya dari anggaran pendapatan belanja daerah (APBD). Dalam beberapa waktu, tidak jarang lembagalembaga kebudayaan atau seni berkunjung untuk mengajukan proposal permohonan dana yang sebenarnya tidak berada dalam jangkauan pihak Dinas Kebudayaan dan Kepariwisataan Provinsi Sulawesi Selatan.

Senada dengan pernyataan
diatas bahwa pembiayaan untuk
kegiatan-kegiatan yang melibatkan
kedua mitra kerja tersebut seperti yang
dikemukakan oleh Staf ASITA bahwa
kemitraan dalam pembiayaan tidak
terjalin dengan baik walaupun
penyertaan modal oleh pihak ASITA
sering dilakukan dibeberapa program
kegiatan promosi yang dimitrakan
keduanya. Pembiayaan dalam segala
kegiataan yang melibatkan keduanya
berasal dari APBD (Anggaran
pendapatan belanja daerah). Dengan
keterbatasan-keterbatasan yang

dimiliki oleh pemerintah dalam hal ini pihak Dinas Kebudayaan dan Kepariwisataan Provinsi Sulawesi Selatan, tidak jarang pihak swasta (ASITA) turun tangan dan ambil bagian berpartisipasi dalam hal pembiayaan program kegiatan yang dimitrakankeduanya.

\section{KESIMPULAN}

Berdasarkan pembahasan yang menyajikan hasil penelitian dan pembahasan maka, pola kemitraan Dinas Kebudayaan dan Kepariwisataan Provinsi Sulawesi Selatan dengan ASITA dalam promosi kunjungan wisata ialah terwujud. Dengan memperhatikan pola kemitraan sebagai indikator yaitu, Pola subkontrak dalam mitra kedua pihak dengan alasan pihak ASITA selalu mendukung kegiatan-kegiatan Dinas Kebudayaan dan Kepariwisataan contohnya menyediakan bus dalam kegiatan tahunan "Lovely Toraja". Pola kemitraan Keagenan terwujud dapat dilihat dari usaha travel naungan ASITA yang memberi pelayanan baik bagi pelanggan sehingga secara langsung juga memberi citra yang baik 
kepada pemerintah sebagai pemelihara dan pengelola destinasi wisata kemudian meningkatlah kunjungan wisata. Kemudian pola kemitraan Modal Ventura atau pembiayaan terwujud karena dana yang digunakan selain berasal dari APBD pemerintah, dana kegiatan berasal dari penyertaan dan dana sukarela dari kedua pihak sesuai dengan ketentuan-ketentuan yang telah disepakati bersama. Akan tetapi, walaupun beberapa pola kemitraan seperti pola kemitraan inti plasma, waralaba dan dagang umum tidak terjalin dengan baik, bukan berarti menjadi hambatan yang berarti karena ketiga pola tersebut memang terfokus dibidang ekonomi sedangkan penelitian terfokus kepada administrasi pemerintahan.

\section{DAFTAR PUSTAKA}

Alma, Buchari. 2006. Market and Promotion.Bandung: Pustaka Latin.

Anoraga, Panji, 2002. Koperasi, Kewirausahaan dan Usaha Kecil. Jakarta: Rineka Cipta.

Farazmand, A. 2009.Building administrative capacity for the age of rapid globalization: A modest prescription for the twentyfirst century. Great Britain:Public Administration Review(November/Decem ber).

Hafsah, 2000. Pengantar Bisnis dan Mitra

UKM.Bandung:Alfabeta

Jayagiri, Hidayat. 2012. Mengenal Kemitraan. Jakarta: Ghalia Indonesia.

Notoatmodjo, Soekidjo, 2003. Pendidikan dan Perilaku Kesehatan. Jakarta: Rineka Cipta.

Noer, Tadjoeddin. 2005. Informasi Dan Potensi Investasi Pariwisata Sulawesi Selatan.

Makassar:Disbudpar Prov. Sul-sel.

Ruslan, 1997. Public Relation and Publicity. Yogyakarta: IKAPI

Savas, E.S, 2000. Privatization And Public Private Partnerships. New Jersey.Catham House Publisher, Inc.

Siswanto, 2002. Promosi dan Pemasaran. Bandung: Alfabeta

Sugiyono, 2012. Memahami Penelitian Kualitatif. Bandung: Alfabeta. 
Sulistiyani, Ambar Teguh. 2004.

Kemitraan dan Model-

Model Pemberdayaan.

Yogyakarta: IKAPI.

Suporahardjo, 2005. Manajemen

kolaborasi. Bogor:Pustaka

Latin.

Swasta, 1998. Pasang Surut Pasar

Modal Indonesia. Jakarta:

Ghalia Indonesia

Sutowo, Pontjo. 2007. Road Map

Pariwisata Indonesia.

Jakarta: Badan Pimpinan

Nasional Pariwisata

Indonesia.

Taslim, 2014.Destinasi Pariwisata

Sulawesi Selatan.

Makassar: Disbudpar

Provinsi Sulawesi Selatan. 